\title{
MODEL PENGEMBANGAN PENDIDIKAN KARAKTER MELALUI PENDIDIKAN AGAMA DI PERGURUAN TINGGI: STUDI KASUS DI UNIVERSITAS SERANG RAYA
}

\author{
DEVELOPMENT'S ROLES OF CHARACTER EDUCATION TOWARDS RELIGIOUS \\ EDUCATION IN UNIVERSITIES: A CASE STUDY AT SERANG RAYA UNIVERSITY
}

\section{Siti Muhibah}

Universitas Sultan Ageng Tirtayasa

e-mail: sitimuhibbah@gmail.com

Naskah Diterima: 29 Oktober 2019; Direvisi: 06 Januari 2020; Disetujui: 25 April 2020

\begin{abstract}
This study aims to determine the pattern of character education development in Islamic Religious Education. The study was conducted at Serang Raya University, Banten in 2019, using a qualitative approach. Data obtained by interview, observation and document techniques. Interviews were conducted with the leaders of the college campus administration staff, religious education lecturers, and students. The results of this study found that the development of character education was implemented through learning in the classroom and student activities, using interactive discussion methods, habituation, exemplary and discipline. The availability of PAI lecturers and campus facilities is a supporting factor for the implementation of character education. In contrast, the inhibiting factors include attitudes and behaviours of students who are less severe in participating in religious activities because they are more focused on science development activities, as well as heterogeneous students.
\end{abstract}

Keywords: Character; Habituation; Education

\begin{abstract}
Abstrak
Penelitian ini bertujuan untuk mengetahui pola pengembangan pendidikan karakter dalam pembelajaran Pendidikan Agama Islam. Penelitian di lakukan di Universitas Serang Raya, Banten pada tahun 2019, dengan menggunakan pendekatan kualitatif. Data diperoleh dengan teknik wawancara, observasi dan dokumen. Wawancara dilakukan kepada pimpinan perguruan tinggi staf administrasi kampus, dosen pendidikan agama, dan mahasiswa. Hasil penelitian ini menemukan bahwa pengembangan pendidikan karakter diimplementasikan melalui pembelajaran di kelas dan melalui kegiatan kemahasiswaan, dengan menggunakan metode diskusi interaktif, pembiasaan, keteladanan dan kedisiplinan. Ketersediaan dosen PAI dan fasilitas kampus merupakan faktor pendukung dari implementasi pendidikan karakter. Sementara faktor penghambat meliputi sikap dan perilaku mahasiswa yang kurang serius mengikuti kegiatan keagamaan karena lebih fokus kepada kegiatan pengembangan sains, serta adanya mahasiswa yang heterogen.
\end{abstract}

Kata Kunci: Karakter; Pembiasaan; Pendidikan 


\section{PENDAHULUAN}

Saat ini pendidikan karakter menjadi trending topic dalam dunia pendidikan. Hal ini dikarenakan kondisi bangsa ini yang menunjukkan perilaku anti-budaya dan antikarakter. Perilaku anti-budaya bangsa ini di antaranya ditunjukkan oleh semakin memudarnya sikap kebhinnekaan dan kegotongroyongan, di samping begitu kuatnya pengaruh budaya asing di tengah-tengah masyarakat kita. Adapun perilaku anti karakter bangsa ini di antaranya ditunjukkan oleh hilangnya nilai-nilai luhur yang melekat pada bangsa Indonesia, seperti kejujuran, kesantunan, kebersamaan bahkan rasa malu sepertinya sedikit demi sedikit telah memudar. Masalah ini cukup menjadi keprihatinan kita bersama, sehingga harus ada usaha untuk menjadikan nilai-nilai itu kembali menjadi karakter yang kita banggakan di hadapan bangsa lain.

Menurut Hayati (2018) Perkembangan gaya hidup yang mengikuti trend budayabudaya barat menyebabkan kecemasan akan memudarnya bahkan hilangnya nilai-nilai etis dan moral. Hal ini menurut Hermawan (2017) dikarenakan pendidikan karakter tidak dapat dilepaskan dari pengaruh masyarakat. Sehingga pada akhirnya menurut Siswanto (2018), pengelolaan pendidikan yang terlalu berlebihan dalam memberi penekanan pada dimensi kognitif dan mengabaikan dimensi-dimensi lain akan melahirkan manusia dengan kepribadian pecah. Lulusan pada saat ini cenderung bersikap sekuler, materialistik, rasionalistik, hedonistik, dan kurang terbina mental spiritualnya dan kurang memiliki kecerdasan emosional. Menurut Faiqoh dan Sahal Mahfudh (2015) bahwa idealnya lembaga pendidikan yang ada di Indonesia di samping menjadi tempat mentransfer ilmu, juga harus menjadi tempat membentuk karakter dan moral peserta didiknya. Bahkan menurut Rosa Susanti (2013) Pendidikan memiliki peran fundamental di dalam pengembangan personal dan sosial, untuk mempercepat laju pembangunan manusia yang harmonis sehingga dapat mengentaskan manusia dari kemiskinan, ketertinggalan, kebodohan, kekerasan, dan peperangan, begitu juga dengan pendidikan karakter.

Sedangkan dalam undang-undang
Sisdiknas No. 20 Tahun 2003 Pasal 3,

Pendidikan nasional berfungsi mengembangkan kemampuan dan membentuk watak serta peradaban bangsa yang bermartabat dalam rangka mencerdaskan kehidupan bangsa, bertujuan untuk berkembangnya potensi peserta didik agar menjadi manusia yang beriman dan bertakwa terhadap Tuhan Yang Maha Esa, berakhlak mulia, sehat, berilmu, cakap, kreatif, mandiri, dan menjadi warga negara yang demokratis serta bertanggung jawab (Indonesia, 2003). Bahkan untuk mendukung perwujudan cita-cita pembangunan karakter sebagaimana diamanatkan dalam Pancasila dan Pembukaan UUD 1945 serta mengatasi permasalahan kebangsaan saat ini, maka Pemerintah menjadikan pembangunan karakter sebagai salah satu program prioritas pembangunan nasional (Perbukuan, 2011).

Oleh karena itu maka tujuan yang paling utama dalam pendidikan adalah membentuk insan yang berakhlak mulia, beriman dan bertakwa terhadap Tuhan Yang Maha Esa, sehingga dunia pendidikan mempunyai tantangan yang sangat berat karena dituntut untuk dapat melahirkan manusia-manusia yang tidak hanya mampu menguasai teknologi dan informasi agar dapat bersaing di dunia internasional akan tetapi juga menjadi manusia yang beriman dan bertakwa kepada Tuhan Yang Maha Esa. Selain itu Pendidikan Agama Islam (PAI) sebagai salah satu bagian dari materi pendidikan mempunyai tanggung jawab untuk dapat merealisasikan tujuan pendidikan Nasional tersebut. Karena tujuan dari pendidikan Islam adalah membentuk insan yang bertakwa, diharapkan melahirkan karakter yang baik.

Penelitian ini juga dilatarbelakangi oleh kegelisahan peneliti yang menyaksikan perilaku dan pergaulan di kalangan mahasiswa yang sangat memprihatinkan, terutama di Perguruan Tinggi Umum Swasta di kota Serang, seperti gaya berpacaran yang berlebihan, cara berpakaian yang memperlihatkan aurat dan lain sebagainya. Hal ini disebabkan karena minimnya penanaman nilai-nilai karakter atau akhlak dan pembelajaran yang diterapkan selama ini lebih menekankan pada keterampilan atau skill untuk bekerja. Oleh karena itu penerapan pendidikan karakter ini sangatlah penting dilaksanakan pada mahasiswa, seperti yang 
diungkapkan Muzayanah (2014) bahwa pembentukan nilai-nilai karakter pada usia remaja sangat penting dalam upaya menangkal pengaruh negatif yang dapat merusak karakter remaja sebagai generasi bangsa. Tak terkecuali dengan Universitas Serang Raya atau lebih dikenal dengan UNSERA yang merupakan salah satu PTU swasta terkenal dan terbesar di kota Serang, yang seharusnya menjadi teladan bagi PTU swasta lainnya di kota Serang.

Berdasarkan uraian di atas, maka rumusan masalah dalam penelitian ini, yaitu bagaimana model pengembangan pendidikan karakter dalam pembelajaran PAI di UNSERA Kota Serang; Bagaimana cara penerapan model pengembangan pendidikan karakter dalam pembelajaran PAI di UNSERA Kota Serang. Berdasarkan dari rumusan masalah di atas, maka tujuan penelitian ini, yaitu untuk mengetahui model pengembangan pendidikan karakter dalam pembelajaran PAI di UNSERA Kota Serang; Untuk mengetahui cara penerapan model pengembangan pendidikan karakter dalam pembelajaran PAI di UNSERA Kota Serang.

\section{KAJIAN PUSTAKA}

Kata 'karakter' sesungguhnya berasal dari bahasa Latin "kharakter", "kharassein", "kharax", dalam bahasa Inggris character, dan dalam bahasa Yunani character, dari charassein yang berarti membuat tajam, membuat dalam (Abdul and Dian, 2011). Hendro (2010) mengartikan karakter sebagai watak, tabiat, pembawaan, dan kebiasaan. Pengertian yang tidak berbeda juga dikemukakan Dharma, (2011) yang mengatakan bahwa arti kata karakter adalah budi pekerti, akhlak, moral, afeksi, susila, tabiat, dan watak.

Dari konsep karakter ini muncul konsep pendidikan karakter. Pendidikan karakter adalah pendidikan nilai, pendidikan budi pekerti, pendidikan moral, dan pendidikan akhlak yang bertujuan mengembangkan kemampuan peserta didik untuk memberikan keputusan baik-buruk, memelihara apa yang baik dan mewujudkan kebaikan itu dalam kehidupan sehari-hari dengan sepenuh hati (Kemendikbud, 2011). Pendidikan karakter adalah bagaimana mengaplikasikan nilai kebaikan dalam bentuk tindakan atau tingkah laku. Oleh karena itu Pendidikan karakter mempunyai makna yang berbeda dengan pendidikan moral yang selama ini didengungkan di negara tercinta ini. Bahkan menurut Priyambodo Erfan (2011) pendidikan karakter mempunyai makna yang lebih dalam. Pendidikan karakter bukan hanya mengajarkan mana yang benar dan mana yang salah, melainkan menanamkan kebiasaan yang baik kepada para peserta didik sehingga mereka memahami perbuatan mana yang benar dan mana yang salah. Setelah itu, diharapkan peserta didik menyenangi perbuatan yang baik tersebut dan mau melaksanakannya dalam kehidupannya sehari-hari.

Ratna Megawangi, (2004) menyatakan bahwa pendidikan karakter adalah sebuah usaha untuk mendidik anak-anak agar dapat mengambil keputusan dengan bijak dan mempraktikkannya dalam kehidupan seharihari, sehingga mereka dapat memberikan kontribusi yang positif kepada lingkungannya. Sedangkan Thomas Lickona (1991) menyatakan bahwa Pendidikan karakter adalah pendidikan untuk membentuk kepribadian seseorang melalui pendidikan budi pekerti, yang hasilnya terlihat dalam tindakan nyata seseorang, yaitu tingkah laku yang baik, jujur, bertanggung jawab, menghormati hak orang lain, kerja keras dan sebagainya.

Pendidikan karakter juga seharusnya membawa peserta didik kepada pengenalan nilai secara kognitif, penghayatan nilai secara afektif, dan akhirnya ke pengamalan nilai secara nyata. Hal yang serupa dikemukakan pula oleh Ratna Megawangi (2004), bahwa ada tiga tahap pembentukan karakter, yaitu (1) Moral Knowing: Memahamkan dengan baik pada anak tentang arti kebaikan; mengapa harus berperilaku baik, untuk apa berperilaku baik, dan apa manfaat berperilaku baik; (2) Moral Feeling: yakni membangun kecintaan berperilaku baik pada anak yang akan menjadi sumber energi anak untuk berperilaku baik dengan cara menumbuhkannya; (3) Moral Action: Bagaimana membuat pengetahuan moral menjadi tindakan nyata. Moral action ini merupakan outcome dari dua tahap sebelumnya dan harus dilakukan berulang-ulang agar menjadi moral behavior. Hal ini senada dengan pendapat Muin (2013) yang mengatakan bahwa 
strategi penguatan karakter dilakukan melalui proses panjang dan berkesinambungan dalam menginternalisasikannya, bahwa penerapan pendidikan karakter tidaklah mudah dapat dilakukan hasilnya secara instan akan tetapi perlu proses yang berkelanjutan.

Pendidikan karakter bertujuan mengembangkan nilai-nilai yang membentuk karakter bangsa yaitu Pancasila, meliputi (1) mengembangkan potensi peserta didik agar menjadi manusia berhati baik, berpikiran baik, dan berperilaku baik; (2) membangun bangsa yang berkarakter Pancasila; (3) mengembangkan potensi warganegara agar memiliki sikap percaya diri, bangga pada bangsa dan negaranya serta mencintai umat manusia (Kemendikbud, 2011). Sedangkan Wiyani (2012), menjelaskan tujuan dari pendidikan karakter adalah untuk mengembangkan potensi peserta didik agar menjadi manusia yang beriman dan bertakwa kepada Tuhan Yang Maha Esa, berakhlak mulia, sehat, berilmu, cakap, kreatif, mandiri, dan menjadi warga negara yang demokratis serta bertanggungjawab. Bahkan Saliman, Widastuti, dan Wulandari (2013) menyatakan tujuan dari pendidikan karakter hendaknya mencakup aspek pembentukan kepribadian yang memuat dimensi nilai-nilai kebajikan universal dan kesadaran kultural di mana norma-norma kehidupan itu tumbuh dan berkembang. Jadi tujuan pendidikan karakter adalah upaya pembentukan sikap dan perilaku peserta didik agar menjadi insan yang baik secara menyeluruh, sesuai dengan nilai-nilai pancasila dan juga nilai-nilai agama.

Pendidikan karakter juga berfungsi (1) membangun kehidupan kebangsaan yang multikultural; (2) membangun peradaban bangsa yang cerdas, berbudaya luhur, dan mampu berkontribusi terhadap pengembangan kehidupan umat manusia; mengembangkan potensi dasar agar berhati baik, berpikiran baik, dan berperilaku baik serta keteladanan baik; (3) membangun sikap warganegara yang cinta damai, kreatif, mandiri, dan mampu hidup berdampingan dengan bangsa lain dalam suatu harmoni (Kemendikbud, 2011).

Pusat Kurikulum Depdiknas (Pusat Kurikulum, 2010) menyatakan bahwa dalam rangka lebih memperkuat pelaksanaan pendidikan karakter pada satuan pendidikan telah teridentifikasi 18 nilai yang bersumber dari agama, Pancasila, budaya, dan tujuan pendidikan nasional, yaitu (1) Religius; (2) Jujur; (3) Toleransi; (4) Disiplin; (5) Kerja keras; (6) Kreatif; (7) Mandiri; (8) Demokratis; (9) Rasa Ingin Tahu; (10) Semangat Kebangsaan; (11) Cinta Tanah Air; (12) Menghargai Prestasi; (13) Bersahabat/ Komunikatif; (14) Cinta Damai; (15) Gemar Membaca; (16) Peduli Lingkungan; (17) Peduli Sosial; dan (18) Tanggung Jawab.

\section{Model pengembangan Pendidikan Karakter}

Adapun model pengembangan pendidikan karakter, menurut Dharma Koesuma (2011) setidaknya ada tiga model, yakni: pertama, model pendidikan karakter berbasis kelas. model ini berbasis pada hubungan dosen sebagai pendidik dan mahasiswa sebagai pembelajar di dalam kelas. Konteks pendidikan karakter adalah proses hubungan komunitas kelas dalam konteks pembelajaran. Relasi antara dosen dengan pembelajar bukan monolog, melainkan dialog dengan banyak arah. Kedua, model pendidikan karakter berbasis kultur sekolah/perguruan tinggi. Desain ini membangun budaya kampus yang mampu membentuk karakter mahasiswa dengan bantuan pranata sosial kampus agar nilai tertentu terbentuk dan terbatinkan dalam diri mahasiswa. Ketiga, model pendidikan karakter berbasis komunitas. Dalam mendidik, komunitas perguruan tinggi negeri maupun swasta tidak berjuang sendirian. Kalau ketiga komponen bekerja sama melaksanakan dengan baik, maka akan terbentuk karakter bangsa yang kuat.

\section{Penerapan Pendidikan Karakter}

Penerapan pendidikan karakter tentunya harus melalui proses yang panjang. Sebelumnya nilai-nilai karakter harus diinternalisasikan terlebih dahulu. Menurut Purwaningsih, Rianawati dan Kartini (2018) internalisasi diartikan sebagai penghayatan, penugasan, penguasaan secara mendalam yang berlangsung melalui pembinaan, bimbingan, penyuluhan, penataran, dan sebagainya. Internalisasi adalah menyatukan nilai dalam diri seseorang, atau dalam bahasa psikologi merupakan penyesuaian keyakinan, nilai, sikap, perilaku (tingkah laku), praktik aturan baku kepada diri 
seseorang. Internalisasi tidak terjadi begitu saja, namun melalui proses seperti bimbingan, binaan dan sebagainya sehingga nilai-nilai yang didapat dari proses internalisasi akan lebih mendalam dan tertanam di dalam diri. Nilainilai karakter itu harus dibiasakan secara terus menerus. Bahkan penerapan nilai-nilai karakter juga harus mendapat dukungan dari lingkungan setempat. Oleh karena itu, maka cara penerapan pendidikan karakter di sekolah atau di kampus dapat dilakukan melalui tiga (3) hal, yaitu: 1) mengintegrasikan butir-butir nilai karakter ke dalam mata kuliah.

Mukhlisin (2015) menyatakan proses integrasi ini dapat dilakukan mulai dari tahap perencanaan, pelaksanaan, dan evaluasi. Pada tahap perencanaan, guru dapat mengadaptasi silabus, RPP, dan bahan ajar yang telah dibuat dengan kegiatan pembelajaran yang bersifat memfasilitasi dikenalkannya nilai-nilai, disadarinya pentingnya nilai-nilai, dan diinternalisasikannya nilai-nilai. Pada tahap perencanaan ini, nilai-nilai pendidikan karakter yang ingin dibentuk dimasukkan dalam PAI dengan melihat Standar Kompetensi (SK). Sedangkan pada tahap pelaksanaan pembelajaran, guru harus memperhatikan materi yang akan diajarkan dengan karakter yang ingin dibentuk. Selain itu, dosen juga harus mampu memilah dan memilih metode yang tepat sesuai dengan karakter yang ingin dibangun, karena karakter tersebut lebih banyak mengarah kepada softskill. (2) pembiasaan dalam kehidupan sehari-hari di kampus (pelayanan, pengelolaan dan pengajaran), dan 3) meningkatkan kerja sama antara lembaga pendidikan, orang tua mahasiswa, dan masyarakat dalam hal membudayakan nilainilai karakter di lingkungan kampus, lingkungan rumah tangga dan lingkungan masyarakat.

Hal ini senada dengan kebijakan Pemerintah bahwa pengembangan pendidikan karakter harus diimplementasikan dalam kurikulum, yaitu mengintegrasikan dalam mata pelajaran atau mata kuliah, mengintegrasikan dalam muatan lokal, dan terdapat kegiatan pengembangan diri seperti pembudayaan dan pembiasaan (seperti kegiatan rutin, kegiatan spontanitas, keteladanan, dan kegiatan terprogram), ekstrakurikuler (seperti pramuka, olah raga, dan seni), dan bimbingan konseling seperti pemberian layanan bagi peserta didik yang mengalami masalah (Kemendikbud, 2011).

Kegiatan pembelajaran dalam kerangka pengembangan karakter peserta didik dapat menggunakan pendekatan belajar aktif seperti pendekatan belajar kontekstual, pembelajaran kooperatif, pembelajaran berbasis masalah, pembelajaran berbasis proyek, pembelajaran pelayanan, pembelajaran berbasis kerja, dan Intoduction, Connection, Application, Reflection, Extension (ICARE) dapat digunakan untuk pendidikan karakter (Kemendikbud, 2011), jadi pada intinya untuk membentuk karakter peserta didik dapat dilakukan dengan berbagai macam pendekatan, yaitu Keteladanan, (2) Penanaman kedisiplinan, (3) Pembiasaan, dan (4) Menciptakan suasana yang kondusif (Furqon, 2010). Namun demikian pembentukan karakter tidak bisa dibentuk dan dibangun dalam waktu yang singkat, pembentukan karakter membutuhkan pengulangan, artinya kegiatan tersebut harus dilakukan berulang-ulang, selain dengan pengulangan juga bisa dengan menggunakan perintah dan larangan akan tetapi perintah dan larangan merupakan bagian terkecil dari pembentukan karakter, yang paling penting adalah membangun kesadaran pada diri peserta didik (Ahmad, 2010).

\section{Pengertian Pendidikan Agama Islam}

Pendidikan diartikan sebagai latihan mental, moral dan fisik (jasmaniah) yang menghasilkan manusia berbudaya tinggi untuk melaksanakan tugas kewajiban dan tanggung jawab dalam masyarakat selaku hamba Allah, maka kependidikan berarti menumbuh kembangkan kepribadian serta menanamkan rasa tanggung jawab (Nur, 1998). Pendidikan Islam adalah pembentukan kepribadian yang memiliki nilai-nilai agama Islam, memilih dan memutuskan serta berbuat berdasarkan nilainilai Islam, dan bertanggungjawab sesuai dengan nilai-nilai Islam (Nur, 1998). Sedangkan menurut Ahmad Tafsir (2005), PAI adalah bimbingan yang diberikan oleh seseorang kepada seseorang agar ia berkembang secara maksimal sesuai dengan ajaran Islam. Menurut Jalaluddin (2001), pendidikan Islam yaitu usaha untuk membimbing 
dan mengembangkan potensi manusia secara optimal agar dapat menjadi pengabdi Allah yang setia.

Abdul Fatah Jalal (1988) menyatakan bahwa sebagian orang mengira ibadah itu terbatas pada menunaikan shalat, shaum pada bulan Ramadhan, mengeluarkan zakat, ibadah haji, dan mengucapkan syahadat. Di luar itu bukan ibadah. Sebenarnya ibadah itu mencakup semua amal, pikiran, dan perasaan yang dihadapkan atau disandarkan kepada Allah. Ibadah adalah jalan hidup yang mencakup seluruh aspek kehidupan serta segala yang dilakukan manusia berupa perkataan, perbuatan, perasaan, pemikiran yang disangkutkan dengan Allah.

Sedangkan tujuan pendidikan agama sebagaimana dalam PP. 55 Tahun 2007 Pasal 2 ayat 2, tentang pendidikan agama dan keagamaan, pendidikan agama bertujuan untuk berkembangnya kemampuan peserta didik dalam memahami, menghayati, dan mengamalkan nilai-nilai agama yang menyerasikan penguasaannya dalam ilmu pengetahuan, teknologi dan seni (Pemerintah, 2007). Dengan demikian, bahwa tujuan pendidikan Islam adalah terbentuknya peserta didik yang menjadi hamba Allah yang taat, memiliki kepribadian yang baik serta mampu memahami dan mengamalkan ilmu pengetahuan, sains dan teknologi. Namun tujuan utama dan yang pertama dalam pendidikan agama adalah penumbuhan dan pengembangan sikap positif dan cinta kepada agama. Sikap inilah yang nantinya akan membuat anak menjadi orang dewasa yang hidup sesuai dengan ajaran agama, berakhlak dan beraktivitas sesuai dengan tuntunan ajaran agama (Nizar, 2009).

Adapun inti dari mata kuliah PAI meliputi hal-hal sebagai berikut: Pertama, Tuhan Yang Maha Esa dan ketuhanan yang mencakup keimanan dan ketakwaan, filsafat ketuhanan. Kedua, manusia yang mencakup tentang hakikat manusia, hakikat dan martabat manusia, tanggung jawab manusia. Ketiga, moral, menyangkut implementasi iman dan takwa dalam kehidupan bersama sehari-hari. Keempat, ilmu pengetahuan, teknologi dan seni, yang mencakup iman, ilmu dan amal sebagai kesatuan, dan kewajiban menuntut ilmu dan mengamalkan ilmu, tanggung jawab terhadap alam dan lingkungan. Kelima, kerukunan antar umat beragama. Yang mencakup agama sebagai rahmat bagi semua, hakikat kebersamaan dalam pluralitas beragama. Keenam, masyarakat. Ketujuh, budaya. Kedelapan, politik dan, kesembilan, hukum, meliputi menumbuhkan kesadaran untuk taat hukum Tuhan, peran agama dalam perumusan dan penegakan hukum yang adil serta fungsi profetik agama dalam hukum (Nur, 2009).

Hubungan antara pendidikan karakter dengan PAI dapat dilihat dalam dua sisi, yakni materi dan proses pembelajaran. Dari segi materi PAI dapat tercakup nilai pendidikan karakter. Menurut Muhsinin (2013) bahwa Pendidikan karakter berdasarkan Islam artinya pendidikan karakter yang mana komponennya mencakup pengetahuan moral, perasaan tentang moral, dan perbuatan moral. Moral-moral tersebut dijajaki dan dikembangkan berdasarkan nilai-nilai Islam (Muhsinin, 2013). Berbagai karakter yang harus dimiliki oleh kaum muslimin menurut Al-Qur'an dan Hadis adalah menjaga harga diri, rajin bekerja mencari rezeki, bersilaturahmi menyambung komunikasi, berkomunikasi yang baik dan menebar salam; jujur, tidak curang, menempati janji dan amanah; berbuat adil, tolong menolong, saling mengasihi dan saling menyayangi; sabar dan optimis; bekerja keras; kasih sayang dan hormat kepada orang tua, tidak menipu; pemaaf dan dermawan; berempati, sedekah, selalu bersyukur, tidak sombong dan angkuh; berbudi pekerti luhur, berbuat baik dalam segala hal, haus mencari ilmu punya rasa malu dan iman; berlaku hemat, konsisten, istikamah, teguh hati, tidak berputus asa, bertanggung jawab dan cinta damai (Muchlas, 2012).

Dalam Islam, pendidikan karakter menjadi hal yang diutamakan. Banyak ayat AlQur'an maupun Hadis Nabi Muhammad SAW yang menjelaskan hal tersebut. Di antara akhlak mulia yang sering disebut dalam Al-Qur'an tercermin dalam sifat kerasulan yang ada pada pribadi Nabi Muhammad seperti fatanah, amanah, sidiq, dan tablig. Rasulullah menjadi teladan yang baik, maka dari itu akhlak tidak diragukan lagi memiliki peranan besar dalam kehidupan manusia. Akhlak menempati kedudukan penting dan dianggap memiliki 
fungsi dalam memandu kehidupan masyarakat (Fitriani, 2015).

Pendidikan karakter bukanlah berupa materi yang hanya bisa dicatat dan dihafalkan serta tidak dapat dievaluasi dalam jangka waktu yang pendek, tetapi pendidikan karakter merupakan sebuah pembelajaran yang diaplikasi dalam semua kegiatan siswa baik di sekolah, lingkungan masyarakat melalui proses pembiasaan, keteladanan, dan dilakukan secara berkesinambungan. Keberhasilan pendidikan karakter ini menjadi tanggung jawab bersama antara sekolah, masyarakat dan orang tua. Evaluasi dari keberhasilan pendidikan karakter ini tentunya tidak dapat dinilai dengan tes formatif atau sumatif yang dinyatakan dalam skor. Tetapi tolak ukur dari keberhasilan pendidikan karakter adalah terbentuknya peserta didik yang berkarakter; berakhlak, berbudaya, santun, religius, kreatif, inovatif yang diaplikasi dalam kehidupan di sepanjang hayatnya. Oleh karena itu tentu tidak ada alat evaluasi yang tepat dan serta merta dapat menunjukkan keberhasilan pendidikan karakter (Nur, 2013). Namun dalam Pendidikan karakter harus ada upaya-upaya yang dirancang dan dilaksanakan secara sistematis untuk menanamkan nilai-nilai perilaku peserta didik yang berhubungan dengan Tuhan Yang Maha Esa, diri sendiri, sesama manusia, lingkungan, kebangsaan yang terwujud dalam pikiran, sikap, perasaan, perkataan, dan perbuatan berdasarkan norma-norma agama, hukum, tata krama, budaya, dan adat istiadat (Wagiran, 2012). Bahkan dalam proses pendidikan karakter harus adanya pemberian tuntunan kepada peserta didik untuk menjadi manusia seutuhnya yang berkarakter dalam dimensi hati, pikir, raga dan rasa serta karsa(Hasan and Zulfaizah, 2018).

Ada dua penelitian terdahulu yang relevan dengan penelitian ini yakni oleh Muthohar di Samarinda dan Herizon di Sleman. Hasil penelitian Ahmad Muthohar (2015) menemukan setidaknya ada 5 strategi model pengembangan pendidikan karakter yang telah dipraktikkan, yaitu 1) mengintegrasikan pendidikan karakter melalui program pembelajaran kurikuler, 2) mengintegrasikan pendidikan karakter melalui kegiatan ko kurikuler, 3) mengintegrasikan pendidikan karakter melalui program pengembangan diri/ekstra kurikuler dan 4) pengintegrasian pendidikan karakter melalui pola pembiasaan rutin dan 5) integrasi antara program kurikuler dan ko kurikuler secara tematik. Penelitian ini ada relevansinya dengan penelitian yang saya bahas yaitu membahas tentang model pengembangan pendidikan karakter, namun perbedaannya adalah dalam penelitian saya tidak hanya sekedar meneliti model pengembangan pendidikan karakter akan tetapi juga meneliti penerapan model pengembangan pendidikan karakter dalam pembelajaran khususnya pembelajaran PAI.

Hasil penelitian lain dipublikasikan oleh Herizon (2012) yang menyimpulkan bahwa proses penanaman karakter kedisiplinan dan tanggung jawab melalui ekstrakurikuler pramuka cukup efektif dalam pembentukan karakter, namun tidak cukup berhasil dalam penanaman disiplin. Penelitian ini sedikit ada relevansinya dengan penelitian yang saya bahas yaitu sama-sama membahas tentang penerapan karakter, namun perbedaannya adalah dalam penelitian saya lebih meneliti tentang model penerapannya dalam pembelajaran, bukan hanya sekedar melalui kegiatan ekstrakurikuler.

\section{METODOLOGI}

Penelitian ini termasuk jenis penelitian kualitatif dengan pendekatan yang bersifat deskriptif dan explanatoris. Teknik pengumpulan data dan informasi menggunakan wawancara, observasi, dan studi dokumen. Wawancara dilakukan dengan dosen yang mengampu mata kuliah PAI dan mahasiswa. Observasi dilakukan dengan pengamatan langsung ke kampus lokus penelitian dan mencatat hasilnya ke dalam checklist atau lembar observasi. Dan studi dokumentasi terhadap catatan, dokumen dan arsip yang relevan.

Setelah data terkumpul, dilakukan analisis atau proses menyusun data agar data tersebut dapat ditafsirkan (Dadang, 2000). Teknis analisis data dilakukan dengan cara reduksi data, display data, verifikasi dan penyimpulan. Reduksi data, berkenaan dengan proses penyeleksian, penyederhanaan, abstraksi, dan perubahan data kasar yang terdapat dalam bentuk tulisan hasil dari catatan lapangan. Display data dalam penelitian ini 
adalah usaha dalam pengumpulan data yang berupa dokumentasi, kurikulum, silabus, RPP, buku ajar, dan kegiatan-kegiatan keagamaan yang diperoleh dari obyek/tempat penelitian. Mengambil kesimpulan dan verifikasi yaitu penarikan kesimpulan dan verifikasi (pembuktian data).

\section{HASIL DAN PEMBAHASAN}

\section{Profil Universitas Serang Raya}

Universitas Serang Raya adalah universitas terkemuka di Banten yang berlokasi di Jalan Raya Serang Cilegon Km. 5 Taman Drangong Serang, Banten. Berdirinya UNSERA berdasarkan Surat Keputusan Menteri Pendidikan Nasional (SK Mendiknas) Tanggal 23 Desember 2008 Nomor: 262/D/O/2008, merupakan realisasi cita-cita Yayasan Pendidikan Informatika (YPI) Serang untuk ikut berpartisipasi dalam mencerdaskan kehidupan bangsa.

Awal mulanya, Yayasan Pendidikan Informatika (YPI) Serang pada tahun 1995 dengan Surat Keputusan Menteri Pendidikan dan Kebudayaan No. 011/D/O/1995 menyelenggarakan Akademi Manajemen Informatika dan Komputer (AMIK) Serang jenjang program Diploma Satu, Dua dan Tiga (DI, DII dan DIII) dengan program studi Manajemen Informatika (MI). AMIK Serang merupakan manifestasi pertama perguruan tinggi yang didirikan YPI Serang setelah sekian tahun mengembangkan program pendidikan kursus komputer mulai dari tahun 1989 seiring dengan kebutuhan masyarakat.

UNSERA memiliki 6 fakultas, yaitu (1) Fakultas teknik, terdiri dari teknik Industri, teknik kimia, teknik sipil. (2) Fakultas Teknologi informasi, terdiri dari teknik Informatika, Sistem Komputer dan Sistem Informasi. (3) Fakultas ekonomi dan bisnis, terdiri dari prodi akuntansi, dan Manajemen. (4) Fakultas ilmu sosial dan ilmu politik, terdiri dari Ilmu komunikasi dan Administrasi Negara. (5) Fakultas keguruan dan ilmu pendidikan, terdiri dari prodi Pendidikan Matematika. (6) Fakultas hukum, terdiri dari Ilmu Hukum. Selain itu juga ada vokasi D3, yaitu komputerisasi Akuntansi, Akuntansi, keuangan dan perbankan, dan Manajemen Perusahaan.
Visi UNSERA adalah menjadi universitas yang kompetitif di tingkat global, berperan serta dalam meningkatkan kesejahteraan masyarakat berlandaskan iman dan taqwa. Misinya adalah menyediakan akses berkeadilan, pendidikan akademis yang berkualitas; melakukan kegiatan Tridharma Perguruan Tinggi yang berkualitas, relevan dengan kebutuhan lokal dan global; menciptakan lulusan yang berkarakter, berkualitas secara akademis dan mampu bersaing di tingkat global; Menciptakan iklim akademik yang mampu mendukung visi.

Adapun rumusan tujuannya, yaitu 1) Menghasilkan lulusan yang berkarakter, berintelektual tinggi, mandiri dan kompetitif di tingkat global; 2) Menciptakan, mengembangkan dan menyebarluaskan ilmu pengetahuan, teknologi dan seni yang relevan dengan kebutuhan lokal dan global untuk mewujudkan kemandirian dan kesejahteraan masyarakat; 3) Menciptakan masyarakat yang berilmu pengetahuan, beradab dan berbudi luhur menjunjung nilai-nilai budaya bangsa; 4) Mewujudkan universitas yang mandiri dan bermartabat.

Berdasarkan Visi, Misi dan Tujuan UNSERA, kegiatan akademik disiapkan dalam suasana yang kondusif untuk proses belajar mengajar, dan memastikan bahwa para mahasiswa akan diperkenalkan dengan metode pendidikan mutakhir di bidangnya. Dengan pendekatan itu, diharapkan lulusan UNSERA akan mempunyai daya saing yang tinggi di lingkungan praktik kerja yang mengglobal dan sangat kompetitif.

\section{Penerapan Kurikulum Pendidikan Agama Islam}

Mata kuliah PAI di UNSERA merupakan salah satu mata kuliah pengembangan kepribadian (MPK) yang wajib dilaksanakan pada semester 1 untuk PAI 1 dan PAI 2 di semester 6. Untuk Materi PAI 1 mengikuti kurikulum nasional yang diperuntukkan bagi Perguruan tinggi Umum, namun juga ditambah dengan muatan-muatan yang disesuaikan dengan kebutuhan mahasiswa saat ini. Sedangkan untuk PAI 2 isi materinya disesuaikan dengan fakultas dan jurusan masing-masing, misalnya Fakultas keguruan 
dan ilmu pendidikan/FKIP maka isi materi PAI 2 nya adalah yang berkaitan dengan pendidikan dalam konsep Islam, Fakultas Ilmu Sosial Dan Politik (FISIP), maka materi PAI 2 berkaitan dengan politik Islam, administrasi negara dalam Islam, dan lain-lain.

Pelaksanaan pembelajaran, dosen PAI UNSERA membuat Satuan Acara Perkuliahan (SAP) yang merupakan penjabaran dari materi pembelajaran tersebut, dan pembelajaran PAI diharapkan akan lebih terarah dan sesuai dengan kebutuhan lokal perguruan tinggi. Pokok-pokok bahasan tersebut, sekurang-kurangnya disampaikan dalam 2 sks. Namun menurut beberapa dosen agama, pokok-pokok bahasan tersebut sangat sulit untuk dipenuhi dengan hanya 2 sks. Oleh karena itu, di UNSERA mata kuliah PAI terebut dapat ditempuh dalam 5 sks yaitu PAI 1 bobotnya 2 sks dan PAI 2 bobotnya 3 sks.

Dosen PAI UNSERA berjumlah 7 orang, dengan latar belakang pendidikan S2 PAI Universitas Al-Azhar Cairo Mesir 3 orang, lulusan S2 Universitas Malaya Kuala Lumpur Malaysia 1 orang, dan S2 UIN Sunan Gunung Jati 3 orang. Mereka ada yang mengambil bidang ilmu agama Islam, ada yang mengambil bidang Syari'ah. Namun walaupun demikian, secara umum mereka adalah ahli di bidang agama Islam.

\section{Model Pengembangan Pendidikan Karakter}

Pendidikan karakter di UNSERA
menjadi skala prioritas yang sangat
diperhatikan bahkan dosen PAI menjadi
benteng pendidikan karakter (Syam, 2019).
Adapun model pengembangan pendidikan
karakter di UNSERA dilakukan melalui pola
pendidikan dalam kelas dan pendidikan di luar
kelas, yaitu sebagai berikut.

\section{Pola Pengembangan di dalam Kelas}

Pola pengembangan pendidikan karakter di dalam kelas dilakukan melalui tahapan perencanaan, pelaksanaan, dan evaluasi.

\section{1) Tahap perencanaan}

Pada tahap perencanaan ini dimulai dengan analisis silabus. Sistematika penulisan silabus PAI UNSERA masih belum memunculkan nilai-nilai karakter yang hendak dicapai, namun secara isi materi sudah cukup banyak materi yang mengandung nilai-nilai karakter.

Secara praktis pengembangan silabus dapat dilakukan dengan merevisi silabus yang telah dikembangkan sebelumnya dengan menambah komponen (kolom) karakter tepat di sebelah kanan komponen (kolom) Kompetensi Dasar atau di kolom silabus yang paling kanan. Pada kolom tersebut diisi nilai-nilai karakter yang hendak diintegrasikan dalam pembelajaran. Nilai-nilai yang diisikan tidak hanya terbatas pada nilai-nilai yang telah ditentukan melalui analisis $S K / K D$, tetapi dapat ditambah dengan nilai-nilai lainnya yang dapat dikembangkan melalui kegiatan pembelajaran (bukan lewat substansi pembelajaran). Kemudian pendekatan/metode pembelajaran harus disesuaikan, agar pendekatan/metode yang dipilih selain memfasilitasi peserta didik mencapai pengetahuan dan keterampilan yang ditargetkan, juga mengembangkan karakter. Prinsip-prinsip pendekatan pembelajaran kontekstual, pembelajaran kooperatif, dan pembelajaran aktif (misal Pembelajaran Aktif, Inovatif, Kreatif, Efektif, dan Menyenangkan (PAIKEM) cukup efektif untuk mengembangkan karakter peserta didik. Selain itu bahan ajar juga harus disiapkan. UNSERA sepertinya belum memiliki buku ajar PAI. Mereka biasanya menggunakan buku-buku teks yang ada di toko-toko buku atau perpustakaan, bukan bahan ajar karangan dosen PAI UNSERA.

\section{2) Pelaksanaan Pembelajaran}

Dalam pelaksanaan pembelajaran terdapat kegiatan pendahuluan, kegiatan inti dan penutup. Dalam kegiatan pendahuluan ketepatan waktu dosen dalam mengawali pembelajaran merupakan salah satu strategi menanamkan sikap disiplin kepada mahasiswa. UNSERA selain mewajibkan mahasiswa memakai pakaian yang sopan, juga mewajibkan mahasiswa datang tepat waktu, jika terlambat maka tidak boleh mengisi absen namun boleh mengikuti perkuliahan. Sikap seperti ini memberikan motivasi kepada mahasiswa untuk selalu datang tepat waktu, karena mereka tidak ingin absensinya kosong atau dianggap tidak hadir. Oleh karena itu untuk membiasakan sikap 
disiplin, maka dosen PAI membuat kontrak perkuliahan yang isinya tentang kesepakatan jam masuk antara dosen dengan mahasiswa yang disepakati secara bersama. Kesepakatan dalam kontrak perkuliahan ini dijadikan pedoman bagi dosen dan mahasiswa dalam melaksanakan perkuliahan.

Selain menerapkan kedisiplinan dalam pembelajaran PAI, dosen juga mengajak para mahasiswa untuk membiasakan membaca basmallah untuk membuka perkuliahan. Makna yang diharapkan dari kebiasaan membaca kalimat tersebut adalah membangun kesadaran dengan sang pencipta agar mendapat keberkahan dari Allah SWT. Selain itu juga, sebelum memulai pembelajaran dosen mewajibkan mahasiswa membaca Al-Qur'an 12 ayat secara bergantian. Dua ayat Al-Qur'an itu sangat mudah diucapkan, akan tetapi dampaknya sangat luar biasa dalam pembentukan sikap religius mahasiswa. Segala perbuatan memang harus dimulai dengan sandaran kepada Allah SWT, Zat Yang Maha Kuasa. Makna spiritualnya, segala tugas mulia merupakan bentuk ibadah kepada Allah SWT, termasuk mulai belajar di kelas. Makna spiritualnya, segala tugas mulia merupakan bentuk Ibadah kepada Allah SWT, termasuk memulai belajar di kelas.

Dengan kebiasaan tersebut secara tidak langsung dosen telah menanamkan nilai-nilai religius dan meningkatkan kecintaan mahasiswa terhadap Al-Qur'an. Nilai-nilai ini kemudian dikembangkan dalam kegiatankegiatan kemahasiswaan di kampus, seperti UNSERA mengaji, mentoring dan lain-lain. Suasana belajar yang nyaman dan didukung dengan penyampaian materi yang dikaitkan dengan kehidupan sehari-hari akan lebih memudahkan mahasiswa untuk memahami materi yang diberikan. Dengan strategi demikian dosen telah menerapkan nilai cinta ilmu dan rasa ingin tahu, serta percaya diri yang kemudian dikembangkan dalam tahap pembelajaran selanjutnya.

Dalam kegiatan inti pembelajaran PAI, dosen memanfaatkan sumber belajar berupa buku paket dengan menggunakan metode ceramah dan diskusi interaktif. Metode belajar tersebut tentunya disesuaikan dengan materi yang akan disampaikan. Sebelum mengawali pembelajaran, dosen terlebih dahulu memberikan pertanyaan-pertanyaan kepada beberapa siswa mengenai materi sebelumnya, kemudian memberi kesempatan kepada mahasiswa untuk berusaha mencari jawaban atau solusi dari pertanyaan tersebut dengan memanfaatkan sumber belajar yang dimiliki. Cara tersebut digunakan untuk menanamkan semangat belajar, rasa ingin tahu, kreatif, dan komunikatif.

Setelah itu, maka membahas materi dengan metode ceramah atau diskusi. Metode diskusi merupakan suatu strategi yang digunakan dosen PAI UNSERA untuk menerapkan nilai disiplin, kerja keras, tekun, dan kreatif. Selain itu, metode diskusi juga diharapkan mampu meningkatkan rasa percaya diri mahasiswa dan mampu menciptakan sebuah proses pembelajaran yang mendukung terbentuknya karakter-karakter positif seperti kritis dan komunikatif. Dengan dosen menyampaikan materi, kemudian melakukan diskusi dengan mahasiswa tentang permasalahan-permasalahan yang terjadi di masyarakat, serta melibatkan mahasiswa secara aktif dalam pemecahan masalah dengan memberikan pertanyaan-pertanyaan, hal ini tentunya dapat mengembangkan pengetahuan mahasiswa dan melatih mahasiswa untuk bekerja keras, kreatif, berpikir logis, dan kritis.

Sementara pada kegiatan penutup dilakukan dosen dengan membacakan hamdalah dan mengucapkan salam. Hal ini dilakukan sebagai strategi menerapkan sikap tanggung jawab terhadap Allah SWT

\section{3) Pelaksanaan Evaluasi}

Evaluasi pembelajaran PAI di UNSERA terdapat tiga komponen yaitu UTS, UAS dan tugas terstruktur. UTS dilaksanakan pertengahan semester jika perkuliahan sudah mencapai 7 pertemuan, sedangkan UAS dilaksanakan pada akhir semester jika perkuliahan sudah dilaksanakan minimal sebanyak 14 pertemuan. Sedangkan tugas terstruktur berupa makalah kelompok. Untuk mengetahui kejujuran dalam pembuatan tugas maka tugas tersebut di tanyakan kembali pada mahasiswa yang bersangkutan tentang judul dan isi makalah ketika UTS atau UAS agar dapat dinilai kejujurannya, apakah tugasnya ada unsur plagiasi atau tidak, begitu pula ketika 
mahasiswa diberikan tugas kelompok, maka untuk mengetahui ikut bekerja sama atau tidak maka ditanyakan kembali judul dan isi tugas tersebut. Bagi mahasiswa yang betul-betul melaksanakan tugasnya dengan baik maka dia akan dapat menjelaskan kembali judul dan isi makalah tersebut, namun sebaliknya bagi mahasiswa yang tidak ikut melaksanakan tugasnya dengan baik maka dia tidak dapat menjelaskan isi makalahnya. Dari situlah akan terlihat mana mahasiswa yang benar-benar jujur atau tidak, dan bekerja sama atau tidak. Itulah salah satu cara evaluasi dosen PAI UNSERA dalam menguji kejujuran mahasiswanya.

Selain itu penerapan pendidikan karakter melalui pembelajaran PAI di UNSERA juga memilik potensi yang strategis. Hal ini dapat dilihat dari tujuan pembelajaran PAI dan isi dari materi PAI itu sendiri, yang lebih dominan untuk membangun pendidikan karakter, terutama nilai karakter religius. Maka tidaklah heran jika dosen PAI di UNSERA menjadi benteng pendidikan karakter karena memiliki tugas utama untuk membentuk karakter mahasiswa UNSERA agar mereka menjadi manusia yang beriman dan bertakwa kepada Allah SWT.

Adapun strategi pengembangan pendidikan karakter dalam pembelajaran PAI di UNSERA adalah sebagai berikut:

a. Diskusi interaktif

Dalam menerapkan pendidikan karakter dalam pembelajaran PAI, maka strategi yang sering digunakan oleh dosen PAI UNSERA adalah metode diskusi interaktif, begitu pula dalam kajian-kajian ilmiah, dan mentoring. Hal ini karena diskusi interaktif merupakan metode yang efektif dalam merangsang mahasiswa untuk kreatif dan kritis terhadap materi-materi yang disampaikan oleh dosen, dibandingkan dengan metode lain seperti ceramah.

\section{b. Metode pembiasaan}

Nilai-nilai karakter yang sudah di pelajari mahasiswa UNSERA, seperti nilai-nilai religius, nilai disiplin, tanggung jawab dan lain-lain tentunya harus dibiasakan dan diterapkan dalam kegiatan mahasiswa sehari-hari, baik dalam kegiatan pembelajaran di kelas maupun kegiatan- kegiatan di luar kelas. Seperti, ketika di dalam kelas, setiap mulai pembelajaran PAI mahasiswa selalu mengawalinya dengan pem-bacaan ayat suci Al-Qur'an dan mengakhirinya dengan membaca hamdalah, harus tepat waktu ketika masuk kuliah dan harus membuat tugas-tugas kuliah. Kebiasaan-kebiasaan ini tentunya sudah tidak aneh lagi di kalangan mahasiswa karena setiap dosen PAI menerapkannya. Kebiasaan-kebiasaan yang baik tentunya harus terus menerus dibiasakan secara rutin, agar menjadi sebuah karakter yang melekat pada diri mahasiswa tersebut, sehingga menjadi budaya kampus.

c. Pendekatan keteladanan

Dosen PAI UNSERA berusaha memberikan teladan yang baik bagi mahasiswanya, baik ketika di dalam kelas maupun di luar kelas. Karena dosen tidak cukup hanya dengan menyuruh mahasiswanya saja untuk berperilaku yang baik, akan tetapi dosen PAI juga harus menjadi pelaku pendidikan karakter artinya dosen harus dapat memberikan contoh yang baik kepada mahasiswanya. Bahkan keteladanan ini dilakukan oleh seluruh unsur dosen PAI, PPKN dan yang lainnya. Mengingat hal ini sangat penting dalam penerapan pendidikan karakter, bahkan harus di dukung oleh semua pihak, baik lingkungan dan budaya setempat. Oleh karena itu seorang pendidik harus berkarakter sebelum membentuk karakter peserta didik, lingkungan juga harus berkarakter agar mendukung aktivitas mahasiswa.

Menurut dosen PAI UNSERA, keteladanan ini juga merupakan metode yang efektif dan efisien dalam penerapan pendidikan karakter, karena mahasiswa pada umumnya cenderung meneladani atau meniru sosok pendidik atau dosennya. Hal ini secara psikologis disebabkan mahasiswa masih ada pada fase labil, yang masih senang meniru, tidak saja meniru yang baik, bahkan terkadang yang jeleknya pun mereka tiru.

\section{d. Metode Kedisiplinan}

Metode kedisiplinan dalam pem-belajaran PAI di UNSERA sudah lama diterapkan, bahkan bukan hanya sekedar mahasiswanya 
saja yang disiplin akan tetapi dosennya pun harus melaksana-kan disiplin. Jadi menurut dosen PAI UNSERA disiplin merupakan salah satu strategi yang dapat menunjang keberhasilan implementasi pendidikan karakter dalam setiap pembelajaran PAI di UNSERA. Fungsi kedisiplinan ini pun adalah untuk dapat mengatur perilaku mahasiswa di kelas agar menjadi teratur, tertib dan tepat waktu sehingga tidak ada mahasiswa yang berkelakuan dan bersikap semaunya sendiri.

\section{Pola Pendidikan Karakter di Luar Kelas}

Implementasi pendidikan karakter di luar kelas adalah melalui kegiatan kemahasiswaan dengan menerapkan proses pendidikan karakter melalui kegiatan yang melibatkan mahasiswa di dalamnya, yaitu (a) lembaga kemahasiswaan, seperti Badan Eksekutif Mahasiswa, Himpunan Mahasiswa, dan LDK, (b) melalui unit kegiatan mahasiswa, seperti pramuka, menwa, olahraga, pencinta alam, dan lainnya. Karena Pendidikan karakter tidak cukup diterapkan melalui pembelajaran di kelas saja, akan tetapi pendidikan karakter juga harus diimplementasikan melalui kegiatankegiatan kemahasiswaan di luar kelas. Adapun nilai-nilai karakter yang dikembangkan dalam kegiatan kemahasiswaan di kampus UNSERA adalah nilai religius, nilai toleransi dan saling menghargai, nilai kedisiplinan, nilai kemandirian, tanggung jawab, peduli lingkungan dan peduli sosial.

\section{1) Nilai Religius}

Untuk mengembangkan nilai-nilai Religius mahasiswa UNSERA, maka ada beberapa kegiatan-kegiatan mahasiswa sebagai penguatan pendidikan karakter dalam mata kuliah PAI di kelas, yaitu:

\section{a. Program UNSERA mengaji}

Setiap mahasiswa UNSERA yang mengambil mata kuliah PAI diwajibkan untuk mengikuti program UNSERA mengaji yang dilaksanakan pada setiap hari jum'at bertempat di Masjid kampus UNSERA dan dibimbing langsung oleh dosen pengampu mata kuliah PAI tersebut. Hal ini bertujuan selain untuk meningkatkan sikap religius mahasiswa UNSERA, juga masih banyak di antara mahasiswa yang belum dapat membaca al-Qur'an dengan baik dan benar terutama dalam masalah tajwidnya, sehingga program UNSERA mengaji ini sudah menjadi kegiatan yang rutin dilaksanakan, bahkan kalaupun dosen PAI sedang berhalangan hadir maka program mengaji akan diganti ke hari yang lain. Dalam kegiatan mengaji ini, semua mahasiswa diwajibkan membawa Al-Qur'an masingmasing dan berpakaian muslim ketika sedang melaksanakan pengajian. Mereka dibimbing satu persatu dalam membaca AlQur'an terutama dalam makharijul hurufnya serta bacaan tajwidnya. Setiap mahasiswa membaca Al-Qur'an minimal 5 sampai 10 ayat. Pada menjelang akhir semester seluruh mahasiswa akan di tes atau ada ujian mengaji. Bagi mahasiswa yang dapat membaca al-Qur'an dengan benar, maka dia dinyatakan lulus, sebaliknya bagi mahasiswa yang belum dapat membaca Al-Qur'an dengan benar maka belum dikatakan lulus, karena pengajian ini merupakan syarat kelulusan pada mata kuliah PAI.

b. Kajian ilmiah

Kajian ilmiah ini dilaksanakan setiap hari kamis dengan pemateri dosen PAI secara bergiliran. Kajian ilmiah ini rutin dilaksanakan tiap minggu dan terbuka untuk semua mahasiswa UNSERA, akan tetapi bagi mahasiswa UNSERA yang mengambil mata kuliah PAI diwajibkan untuk mengikuti kajian ilmiah ini. Adapun tema dalam kajian ilmiah ini adalah masalah-masalah keagamaan dan masalah-masalah kekinian. Selain itu, di UNSERA juga terdapat Kajian Ruhul Islam, KAMUS atau kajian mahasiswa UNSERA yang dilaksanakan oleh Lembaga Dakwah Kampus.

c. Kegiatan Mentoring,

Kegiatan mentoring di UNSERA merupakan kegiatan pembinaan keagamaan tentang fiqih ibadah, seperti fiqih shalat, fiqih puasa, zakat dan haji. Hal ini dikarenakan masih banyak di antara mahasiswa UNSERA yang belum dapat melaksanakan shalat dengan baik dan benar, oleh karena itu setiap mahasiswa yang mengambil mata kuliah PAI diwajibkan untuk mengikuti kegiatan mentoring. Adapun waktu pelaksanaan 
mentoring ini disesuaikan dengan jadwal perkuliahan dan dibimbing langsung oleh dosen PAI.

d. Kegiatan perayaan hari besar Islam
Mahasiswa UNSERA juga selalu memperingati hari-hari besar Islam seperti Maulid Nabi Muhammad SAW, Isra' Mi'raj dan kegiatan ramadhan. Kegiatan-kegiatan ini biasanya kepanitiaannya melibatkan mahasiswa dari Organisasi mahasiswa (ORMAWA) seperti LDK dan Himpunan Mahasiswa Jurusan atau HMJ.

2) Nilai toleransi dan saling menghargai

UNSERA memiliki mahasiswa yang bersifat heterogen, karena UNSERA merupakan Perguruan tinggi umum sehingga tidak sedikit jumlah mahasiswa UNSERA yang berlainan agama atau sering disebut dengan Nonis (Non Islam). Dalam perkuliahan dosen PAI sering membahas tentang pentingnya toleransi, dengan melatih mereka untuk menghargai sesama, menghargai pendapat orang lain, seperti ketika diskusi kelompok atau adu argumen di kelas atau dalam kajian ilmiah. Sekalipun terjadi perbedaan pendapat, tetapi harus disampaikan dengan argumen-argumen yang santun dan fakta-fakta yang logis atau disertai bukti ayat Al-Qur'an. Sehingga dalam pergaulan sehari-hari di kampus mahasiswa UNSERA sudah biasa bergaul dengan yang Noni, walaupun mereka berlainan agama, mereka saling mengingatkan dalam beribadah dan mereka juga sudah terbiasa menjalin pertemanan dengan mahasiswa yang berbeda agama.

\section{3) Nilai Kedisiplinan}

Penerapan nilai kedisiplinan di UNSERA lebih ditekankan dalam proses pembelajaran ketika masuk kelas. Cara seperti ini lebih tepat dan efektif, mengingat dosen sendiri yang memantau dan memberikan sanksi. Dalam kegiatan perkuliahan di kelas baik dosen maupun mahasiswa harus tepat waktu sesuai dengan kesepakatan dalam kontrak perkuliahan.

4) Peduli lingkungan dan sosial

Dalam menerapkan kepedulian sosial mahasiswa, maka Rektor UNSERA selalu menginstruksikan kepada seluruh sivitas akademik untuk memberikan bantuan kepada masyarakat yang terkena musibah atau bencana alam seperti musibah tsunami Palu, Lombok, Banten dan lain-lain. Mahasiswa UNSERA mengadakan penggalangan dana dan mengumpulkan pakaian layak pakai untuk membantu masyarakat korban Tsunami tersebut. Kepedulian sosial juga terwujud melalui iuran kelas yang dihimpun dan diperuntukkan untuk kegiatan bersama dalam kelas itu seperti menengok temannya yang sedang sakit atau terkena musibah lainnya.

Untuk menanamkan kepedulian lingkungan, mahasiswa UNSERA baru-baru ini telah mengadakan pemurnian air di desa binaan yaitu desa Tunjung Teja, memberikan keterampilan pada masyarakat yaitu tentang cara pengolahan kulit kerang yang di bikin hiasan. Pada waktu-waktu tertentu mahasiswa UNSERA juga suka mengadakan kebersihan kali di lingkungan kampus, dan membersihkan Musolla di sekitar lingkungan UNSERA.

5) Nilai Kemandirian dan tanggung jawab

Dalam mengembangkan nilai kemandirian dan tanggung jawab, maka mahasiswa UNSERA dalam setiap kegiatankegiatan kemahasiswaan di kampus diberikan tanggung jawab dalam mempersiapkan acara bahkan dalam pencarian dana, mereka tidak melulu mengharapkan dana dari kampus akan tetapi mahasiswa berusaha mencari dana dengan meminta bantuan di luar kampus atau mencari donatur. Mereka pun aktif dalam kepanitiaan kegiatan-kegiatan di kampus seperti kegiatan hari besar Islam, seminar, Pramuka dan lain-lain.

\section{Faktor Pendukung dan Penghambat}

Adapun faktor-faktor pendukung dalam penerapan pendidikan karakter mahasiswa UNSERA adalah (1) sarana prasarana yang memadai baik sarana pembelajaran, sarana kegiatan-kegiatan mahasiswa, maupun sarana ibadah. (2) Memiliki dosen-dosen PAI yang mumpuni dibidangnya, sudah S2 dan rata-rata lulusan dari Cairo Mesir.

Namun demikian, dalam penerapan pendidikan karakter di kalangan mahasiswa terkadang tidaklah mudah dan banyak menemui kendala, hal ini dikarenakan karakter mereka sudah terbentuk sebelum masuk ke perguruan 
tinggi. Namun walaupun demikian, perguruan tinggi dituntut untuk berperan aktif dalam menerapkan pendidikan karakter pada diri mahasiswanya.

Sementara yang menjadi faktor penghambat dalam melaksanakan pendidikan karakter di UNSERA, yaitu Pertama, ada beberapa mahasiswa yang acuh tak acuh untuk mengikuti kegiatan-kegiatan keagamaan di kampus, sehingga terkadang dosen merasa kesulitan mengajak mahasiswa tersebut, karena UNSERA merupakan perguruan tinggi umum yang lebih fokus kepada pengetahuan umum atau sains dan teknologi. Kedua, menerapkan pola berpakaian juga agak sulit karena tipologi mahasiswa yang heterogen, sehingga dosen hanya dapat menganjurkan tapi tidak menekankan atau memberikan sanksi dan pada akhirnya mereka berpakaian bebas ada yang memakai jeans atau kaos yang penting sopan.

Uraian di atas memberikan gambaran, bahwa penerapan pendidikan karakter tidaklah mudah dapat terealisasi di perguruan tinggi umum. Perlu adanya dukungan dari semua pihak, sehingga dalam menerapkan pendidikan karakter bukan hanya tugas dosen PAI saja, akan tetapi semua unsur pendidikan (baik dosen-dosen, tenaga kependidikan, maupun lingkungan) harus memahami dan mendukung dalam implementasinya. Walaupun dosen agama yang selalu menjadi sorotan utama, namun karena penerapan pendidikan karakter tidak hanya di dalam kelas saja, akan tetapi lingkungan juga harus mendukung maka tanggung jawab penerapannya adalah semua sivitas akademik kampus harus menjadi kurikulum hidup pendidikan karakter. Apabila mahasiswa tidak menemukan teladan dalam pribadi dosennya atau lingkungan tidak mendukungnya, maka akan sulit karakter tersebut dapat terbentuk.

Selain dosen dan lingkungan, orang tua juga mempunyai peranan penting dalam menyukseskan pendidikan karakter, karena keluarga merupakan pendidikan pertama bagi anak. Karakter itu harus dibangun sedini mungkin sebelum memasuki sekolah, bahkan kalau dalam pendidikan Islam, upaya itu dapat dimulai sejak pemilihan jodoh dan dilanjutkan dalam kandungan (pendidikan pranatal) serta ketika sudah lahir. Hal ini dikarenakan untuk memperoleh generasi yang berkarakter juga harus diawali dengan pemilihan pasangan yang berkarakter, karena orang tua juga akan menurunkan sifat-sifatnya kepada anaknya. Kemudian ketika di dalam kandungan, anak juga akan belajar dari apa yang yang dilakukan oleh orang tuanya, terutama ibunya. Setelah lahir, maka orang tua harus memberikan teladan yang baik bagi mereka. Dengan demikian, pendidikan yang sudah mereka peroleh di dalam lingkungan keluarganya akan mudah dikembangkan di lingkungan sekolah, kampus dan masyarakat.

\section{PENUTUP}

Model penerapan pendidikan karakter di perguruan tinggi umum dapat dilakukan melalui mata kuliah Pendidikan agama, sebagaimana diterapkan di UNSERA adalah dengan mengimplementasikan pendidikan karakter melalui pembelajaran di kelas dan di luar kelas terutama melalui kegiatan kemahasiswaan. Hal tersebut dilakukan melalui metode diskusi interaktif, metode Pembiasaan, metode keteladanan, dan metode kedisiplinan. Faktor pendukung terselenggaranya pendidikan karakter melalui Pendidikan agama di perguruan tinggi umum, di antaranya adalah ketersediaan sarana prasarana pembelajaran, kegiatan mahasiswa, maupun sarana ibadah; serta ketersediaan dosen PAI yang mumpuni dibidangnya, sudah S2 dan rata-rata lulusan dari Cairo Mesir. Sedangkan beberapa faktor penghambat, adalah budaya Perguruan Tinggi Umum dengan heterogenitas mahasiswa yang berasal dari latar belakang yang beragam. Beberapa mahasiswa ada yang acuh tak acuh mengikuti kegiatan keagamaan; pola berpakaian (fashion-style) yang dipengaruhi oleh variabel eksternal kampus. Beberapa mahasiswa memakai jeans atau kaos yang penting sopan.

\section{UCAPAN TERIMA KASIH}

Atas selesainya artikel ini, saya menghaturkan terima kasih kepada Puslitbang Pendidikan Agama dan Keagamaan yang telah mendanai risetnya. Kepada pimpinan Universitas UNSERA, dosen, dan mahasiswa, juga saya haturkan terima kasih atas kesediaan dan dukungan dalam mengumpulkan data dan informasi yang relevan. Kepada para peneliti 
Puslitbang Pendidikan agama dan Keagamaan, yang menjadi pembimbing riset dan penulisan laporan serta penulisan artikel ini, juga tidak lupa saya haturkan terima kasih

\section{DAFTAR PUSTAKA}

Abdul, F. J. (1988) Azaz-azaz Pendidikan Islam. Bandung: Diponegoro.

Abdul, M. and Dian, A. (2011) Pendidikan Karakter Perspektif Islam. Bandung: Remaja Rosdakarya.

Ahmad, M. (2010) Pendidikan Karakter. Jakarta: Prenada Media Grup.

Ahmad, M. (2015) Model Pengembangan Pendidikan Karakter: Studi pada SMP di kota Samarinda. Samarinda.

Ahmad, T. (2005) Ilmu Pendidikan dalam Perspektif Islam. Bandung: Remaja Rosdakarya.

Dadang, K. (2000) Metode Penelitian Agama (Perspektif Ilmu Perbandingan Agama). Bandung: Pustaka Setia.

Dharma, K. (2011) Pendidikan Karakter: Kajian, Teori dan Praktek di Sekolah. Bandung: Ramaja Rosdakarya.

Erfan, P. (2011) 'Penerapan Pendidikan Karakter dalam Pembelajaran sebagai salah satu wujud Profesionalisme Guru', Jurnal Cakrawala Pendidikan, 30(edisi khusus), p. 179.

Faiqoh and Sahal, M. (2015) 'Model Pembentukan Karakter Religius Santri Tahfidz Al-Qur'an di Pondok Pesantren Mathali'ul Huda Pusat Kajen Pati', Edukasi; Jurnal Penelitian Pendidikan Agama dan Keagamaan2, 13(3), p. 350.

Fitriani, N. (2015) 'Implementasi Pendidikan Karakter dalam Pendidikan Agama ISlam di SDIT Luqmanul Hakim Bandung', Jurnal Tarbawy, 2(1), p. 26.

Furqon, H. (2010) Pendidikan Karakter Membangun Peradaban Bangsa. Surabaya: Yuma Pustaka.

Hasan, B. and Zulfaizah (2018) 'Revitalisasi Pendidikan Agama dalam Pembentukan Karakter PEserta Didik di Madrasah', Jurnal Elementary, 6(1), p. 48.
Hendro, D. (2010) Kamus Ilmiah Populer Lengkap. Yogyakarta: Bintang Cemerlang.

Herizon (2012) Penerapan Karakter Kedisiplinan dan Tanggung Jawab terhadap Peserta didik dalam Kegiatan Ekstrakurikuler Pramuka di SMAN Tempel Sleman. UIN Sunan Kalijaga Jogjakarta.

Indonesia, P. (2003) Undang - Undang Sistem Pendidikan Nasional. Indonesia.

Jalaluddin (2001) Teologi Pendidikan. Jakarta: Raja Grafindo.

Kemendikbud, R. (2011) Panduan Pelaksanaan Pendidikan Karakter. 1st edn. Edited by P. Kurikulum. Jakarta: Kemendikbud.

Muchlas, S. H. (2012) Konsep dan Model Pendidikan Karakter. Bandung: Remaja Rosdakarya.

Muhsinin (2013) 'Model Pendidikan Karakter Berbasis Nilai-Nilai Islam untuk Membentuk Karakter Siswa yang Toleran', Jurnal Edukasia, 8(2).

Muin, A. (2013) 'Penguatan Karakter Melalui Pendidikan Islam di TK Mawaddah Kota Banjarmasin', Edukasi: Jurnal Penelitian Pendidikan Agama dan Keagamaan, 11(2).

Mukhlisin, N. (2015) 'Pengembangan PAI Berbasis Pendidikan Karakter', Inovatif, 1(2), p. 44.

Muzayanah, U. (2014) 'Strategi Pendidikan Karakter pada Madrasah Tsanawiyah Muhammadiyah 01 Purbalingga, Jawa Tengah', Edukasi; Jurnal Penelitian Pendidikan Agama dan Keagamaan, 12(3), p. 399.

Nizar, R. (2009) Filsafat Pendidikan Islam. Jakarta: Kalam Mulia.

Nur, A. (2009) Orientasi Pengembangan Pembelajaran Pendidikan Agama Islam di Pergu ruan Tinggi. Malang: UIN Maliki.

Nur, A. (2013) 'Pembentukan Karakter Melalui Pendidikan Islam', Jurnal Al-Ulum, 13(1), p. 28. 
Nur, U. (1998) Ilmu Pendidikan Islam. Bandung: Pustaka Setia.

Pemerintah, P. (2007) Pendidikan Agama dan Keagamaan. Indonesia.

Perbukuan, P. K. dan (2011) Panduan Pelaksanaan Pendidikan Karakter. Jakarta.

Purwaningsih, Rianawati and Kartini (2018) 'Internalisasi Nilai-Nilai Karakter pada Pembelajaran Pendidikan Agama Islam di SMP Negeri 4 Sungai Raya', JRTIE: Journal of Research and Thought of Islamic Education, 1(1), p. 122.

Pusat Kurikulum, D. (2010) Kebijakan Pendidikan Karakter Bangsa. Jakarta: Kemdiknas.

Ratna, M. (2004) Pendidikan Karakter: Solusi Tepat untuk Membangun Bangsa. Bogor: Heritage Foundation.

Rosa, S. (2013) 'Penerapan Pendidikan Karakter di Kalangan Mahasiswa', Jurnal Al-Ta'lim, 1(6), p. 480.
Saliman, Widiastuti, A. and Wulandari, T. (2013) 'Persepsi dan Sikap Mahasiswa terhadap Pendidikan Karakter di Prodi Pendidikan IPS UNY', Social: Jurnal Ilmu-Ilmu Sosial, 2(1).

Syam, S. D. (2019) 'Pendidikan Karakter di UNSERA'.

Thomas, L. (1991) Educating for Character, How Our Schools Can Teach Respect and Responsibility. Newyork: Bantam Books.

Wagiran (2012) 'Pembentukan Karakter Melalui Pendidikan Agama', Jurnal Pendidikan Karakter, 13(1), p. 34.

Wiyani (2012) Manajemen Pendidikan Karakter, Konsep dan Implementasinya di Sekolah. Yogyakarta: Pegagja. 